\title{
REFLECTIONS ON THE NATURE OF NEW TESTAMENT GREEK VOCABULARY ${ }^{1}$
}

\section{Colin J Hemer +}

It is noteworthy that the principal thrust of interest in the study of biblical Greek in the last generation has been theological. We have 'Kittel' and the Begriffslexikon and its English counterpart, ${ }^{2}$ as well as extensive collections of theological word-studies by such scholars as C. Spicq and N. Turner. ${ }^{3}$. This theological interest is of course entirely proper, and indeed in its place a crucially important subject of study. But I see a danger if this natural interest is permitted to distort a balanced appraisal of the nature of biblical, particularly New Testament, language as a whole. On any view there are continuities as well as discontinuities with contemporary secular language, and it may be at least an important corrective to focus on the complementary aspect. It now seems that the available lexica, for all their acknowledged excellences, are variously dated or

${ }^{1}$ An initial stimulus to my choice of subject was G. H. R. Horsley's recent review article, 'Divergent Views on the Nature of the Greek of the Bible', Biblica 65 (1984) 393-403, which compares the divergent perspectives on biblical Greek in Nigel Turner, Christian Words (Edinburgh, T \& T Clark 1980) and J. A. L. Lee, A Lexical Study of the Septuagint Version of the Pentateuch (SCS 14; Chico, Scholars Press 1983). My intention was not so much to enter the lists of a longstanding controversy as to attempt some general reflections and reformulations as a constructive contribution to the debate, and to draw on the ancient nonliterary documents, especially the neglected inscriptional texts, for the illustrative evidence. That basic intention has not changed, but since the first stimulus, some of my hopes have been carried a step further towards fruition in the progress made at the Princeton conference of December 1985 on a proposed new lexicon of the Greek New Testament. This paper will conclude with a short report on the prospects opened by that meeting.

2 G. Kittel (ed.), Theologisches Wörterbuch zum Neuen Testament (10 vols.; Stuttgart, Kohlhammer 1933-79); Theological Dictionary of the New Testament tr. G. W. Bromiley (10 vols.; Grand Rapids, Eerdmans 1964-76); L. Coenen, E. Beyreuther and H. Bietenhard (eds.), Theologisches Begriffslexikon zum Neuen Testament (3 vols.; Wuppertal, Brockhaus 1967-71); C. Brown (ed.), The New International Dictionary of New Testament Theology ( 3 vols.; Exeter, Paternoster 1975-8).

3 C. Spicq, Notes de Lexicographie né-testamentaire (3 vols.; Fribourg and Göttingen, Editions Universitaires and Vandenhoeck \& Ruprecht 1978-82); N. Turner, Christian Words. 
inadequate for the fuller linguistic description of Koine Greek, as a necessary control upon the discussion of the influence of theological creativity upon vocabulary. ${ }^{4}$ A. Deissmann and J. $H$. Moulton undoubtedly carried the enthusiasm of a new vision too far: Turner stands near the opposite end of a spectrum of opinion. There are valid observations underlying both extremes, but their relative strength can only be assessed under the strict controls of detailed study, for which recent developments in computerization have opened up a new facility. And the issue has a wider application. Did the apostles speak and write in an idiom approximating to the everyday usage of their time? Or was there an early development of a technical religious vocabulary? The answer may have something to teach us of the nature of the first Christian interaction with society and offer its lessons also for our modern modes of communication.

I suspect that Turner is right in the sense that the language of a first-generation Christian may have been substantially different from that of a contemporary pagan in a different walk of life. But that probability may be of relatively less significance than he might wish to claim. It might be highly instructive to make a comparative description of the English usage of a teenage mother of twins and a retired bachelor candlestick-maker. We might be surprised how different they were, and the reasons for that difference might be remarkably complex and elusive. Moreover, language is inseparable from communication, and the internal communication between groups of persons in each category might modify and accentuate their differences in a degree which might tempt us to want to describe them as separate varieties of English. But I submit that we could only do that in a quixotic sense. Unless our research were directed simply to demonstrate the phenomenon of 'idiolect', it would be of small linguistic significance. A more balanced linguistic description of English usage must have regard to a wider spectrum of community, within which suprisingly wide trivial differences co-exist. Our concern is with 4 LSJ, while comprehensive in its general coverage, focuses on classical
literature, and is marginal and sometimes misleadingly incomplete in its
treatment of this period. BAGD is indispensable, but focuses inevitably on the
limited spectrum of literature it covers. It cannot provide a fuller contextual
description, and is weakest in its coverage of documentary, especially epigraphic,
sources. Cf. Towards a New Moulton and Milligan', NooT 24 (1982) esp. 117-18. 
what F. de Saussure called langue, as opposed to parole. ${ }^{5}$

We might analyze the case in terms of the familiar notion of a threefold concentric personal vocabulary range, the largest a vocabulary of recognition, the second a writing vocabulary, the third and narrowest the speaking vocabulary. The range and content of all three circles will vary from individual to individual, but that of recognition will in all cases be both the largest and the nearest to a norm shared with other speakers. The 'recognition vocabulary' of a first-century Greek-speaker is of course irretrievably lost to us, as is his individual speaking vocabulary. But we have, in fragmentary and piecemeal form, a vast array of fragments of the writing vocabularies of a wide range of persons, from the highest literature to the jottings of the marginally literate. And within this spectrum we have much greater diversity than the student reared on classical Attic, or on standard 'Wenham', might ever suspect. But the task of lexicography must inevitably be addressed to a more comprehensive level, to what we might term the cumulative recognition vocabulary of a community, so far as this is recorded in the whole range of its surviving documents, subject only to such practical limits as usefulness to a chosen audience or as complementing the coverage of existing dictionaries.

In a paper like the present it might be tempting to focus on particular instances of documentary usage in the inscriptions or papyri which appear to illuminate the New Testament. But my purpose is to attempt to look a little deeper into the underlying character of its language, with regard to the kinds of variety which existed in the Greek of the period. I shall suggest that there were in fact many kinds of variety within what we must still treat as essentially one linguistic entity. And Turner's 'Christian Words' must still be described within the description of that larger entity. I am not denying for a moment that Christian theology exercised, sooner or later, a profound

5 F. de Saussure, Course in General Linguistics, tr. W. Baskin (London, Fontana/Collins/1974) 14-15, 17-20; cf. the Introduction by J. Culler, xvii-xviii. The French Cours de linguistique generale was apparently first published in 1916. For an application of these linguistic principles to the New Testament $\mathrm{cf} . \mathrm{M}$. Silva, 'Bilingualism and the Character of Palestinian Greek', Biblica 61 (1980) 198-219. Cf. generally Silva's other recent writings, including 'Semantic Borrowing in the New Testament', NTS 22 (1976) 104-10; 'The Pauline Style as

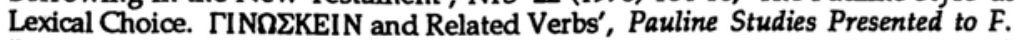
F. Bruce, ed. D. A. Hagner and M. J. Harris (Exeter, Paternoster 1980) 184-207, also his review of Turner's Christian Words in T) n.s. 3 (1982) 103-9. 
influence upon religious vocabulary, but the evaluation of these factors must be subject to the control of a more comprehensive kind of description.

\section{KINDS OF VARIATION IN THE GREEK OF THE ROMAN EMPIRE}

\section{Dialect}

It is an old question whether we can speak of 'dialects' within the Koine and Moisés Silva has shown how this matter can be bedevilled by lack of definition. ${ }^{6}$ Albert Thumb argued that there were no dialects, not, that is, in the sense of major phonetic, structural and syntactical diversities comparable with those which mark off differences in the traditional Ionic/Attic, Doric and Aeolic divisions of older Greek - not differences in fact in langue, in its broader sense. ${ }^{7}$ Without pressing the term 'dialect' in this sense, I think it is at least possible to show that there were locally-based variations within the 'common' Greek, and that some of these may be presented more analytically under some of the following heads. Doric and Aeolic forms themselves show unexpected persistence in the documents. ${ }^{8}$

${ }_{7}^{6}$ M. Silva, Biblica 61 (1980), esp. $204-6$.

7 A. Thumb, Die griechische Sprache im Zeitalter des Hellenismus (Beitrdge zur Geschichte und Beurteilung der Kovm) (Strassburg, Trübner 1901) 162-201. the term consistently while Thumb himself never actually defines 'dialect', he uses the term consistently of major divisions of langue, and is supported in this usage his article 'Grec bibliqu', in his article 'Grec biblique', in Dictionnaire de la Bible, Supplément 3 (Paris, same thing, and the same point is (see e.g. 1361ff.) is not talking about quite the differences here go beyond quint is perhaps also applicable to Turner, though the 8 The distinctive beyond questions of formulation.

indigenous, even in forms persist in the areas where the old dialects were indigenous, even in official documents, sometimes alternating arbitrarily with more standardized language. The phenomenon could be illustrated in hundreds of documentary texts. It will suffice to offer typical examples. The Doric of Maiuri, Nuova silloge epigrafica di Rodi e Cos (Firenze, Felice le Monnier 1925), e.g. nos 461, 462 (after Claudius); 468a, b (both of Claudius) show fluctuation between dialectal and standard forms. For an 'Aeolic' example cf. the lengthy decree of Cyme in Aeolis in SEG 32 (1982) 1243, from the time of Augustus. IGRR 3.91-2, of Mytilene, show dialectal forms as late as Septimius Severus. 


\section{The Diverse Influences of Substratal languages}

F. T. Gignac has recently drawn attention to the frequency of $\pi$ for $\beta$ and $\tau$ for $\delta$ in the papyri, as representing a distinctively Egyptian substratum, the voiced stops being absent from Coptic pronunciation. 9 Instances of much more complex lexical and syntactical interest will be found in the Greek inscriptions of Phrygia, where a strangely illiterate patois with recurring eccentricities is immortalized on stone in an area coincident with and extending a little west of the limits of the neo-Phrygian language texts. ${ }^{10}$ In this region we observe repeatedly $\pi \delta s$ for $\pi p o s$, confusion of $\lambda$ with $\rho$ and of genitive with dative, the use of unparalleled compound verbs, and many anomalous constructions and corrupt words. The occurrence of unique words in this context is probably often to be related to the substratum, where strange compounds, for instance, may be explained as uncultivated 'calques' of Phrygian archetypes, such

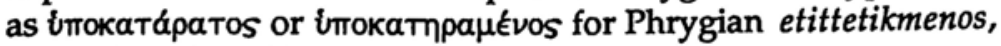

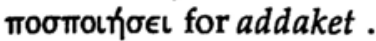

\section{Social and Stylistic Variations}

A large number of very interesting categories may be brought under this general heading. A factor to be observed in the Greek of the Early Empire is the Atticizing movement, which became a dominant influence in the second century. In literature this movement is most familiar in the work of Lucian, but its theory is exemplified in such curious works on Greek usage as that of Phrynichus, a kind of ancient 'Fowler' which exhibits a mixture of stylistic good sense and extremes of conservative pedantry. ${ }^{11}$

${ }^{9}$ F. T. Gignac, 'The Pronunciation of Greek Stops in the Papyri', TAPA 101 (1970) 185-202.

${ }^{10}$ These texts may conveniently be found in the relevant volumes of MAMA (esp. vols. 4, 7). The remains of Neo-Phrygian are most conveniently collected in O. Haas, Die phrygische Sprachdenkmäler (Sofia, Academie bulgare des sciences 1966) or in J. Friedrich, Kleinasiatische Sprachdenkmäler (Berlin, W. de Gruyter 1932), Neophrygische Texte' 128-40. For virtual bilinguals to establish the

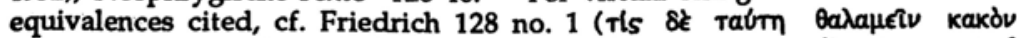

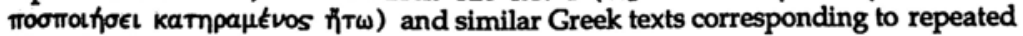
Phrygian formulations.

11 Die Ekloge des Phrynichus, ed. Eitel Fischer (Berlin and New York, Walter de Gruyter 1974). 
It may be largely due to the influence of such stylistic theories that our remains of first century Greek literature are relatively sparse, ${ }^{12}$ apart from scientific and Christian writings whose importance rested on their content for their audience, and were despised for their style by later purists. A few examples which touch the New Testament may be of interest. Among the words

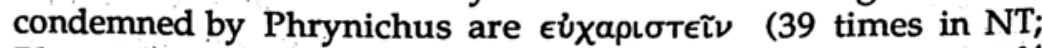
Phrynichus Ecl. 10), ${ }^{13}$ крáßatros (11 times; Phryn. 41), ${ }^{14}$ кopáalov (7 times in Mt. and Mk.; Phryn. 50), ${ }^{15}$ па́vтоте (41

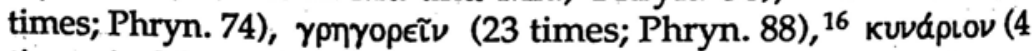
times in Mt. and Mk.; Phryn. 151), $\beta \rho \in \chi \in L$ (7 times; Phryn.

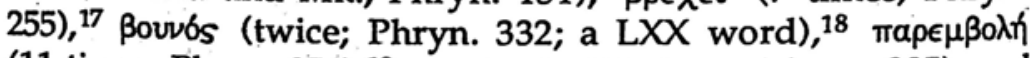

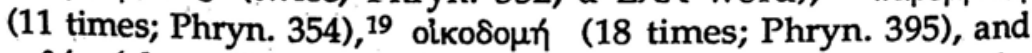
кaÁs (about 182 times; Phryn. 399). In most of these cases the approved alternatives are absent from the New Testament, but Luke wins a good mark by using $\beta \in \lambda \sigma v \eta$ (Lk. 18:25) beside pa $\phi i s$ in the otherwise precisely parallel Mt. 19:24 = Mk. 10:25, where

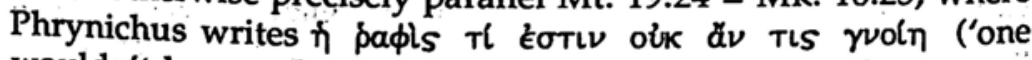
wouldn't know what on earth it is' 63). Similar strictures are

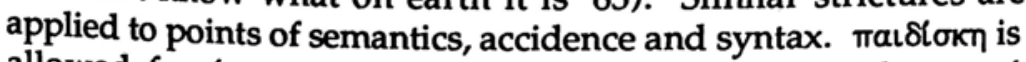
allowed for 'young woman' (veavis), not for 'maidservant' $(\theta \in p d \pi a \nu v a)$, as perhaps always in the New Testament (13 times;

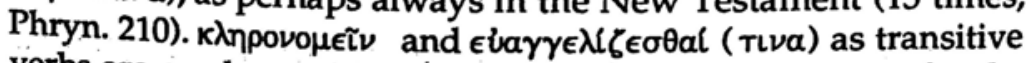
verbs are condemned (Phryn. 100, 232), as is the passive for the

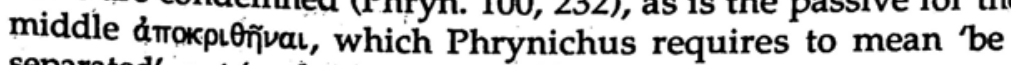
separated', not 'reply' (Phryn. 78). 20

\footnotetext{
${ }_{12}^{12}$ Cf. E. A. Judge, 'St Paul and Classical Society', JAC 15 (1972) 21.

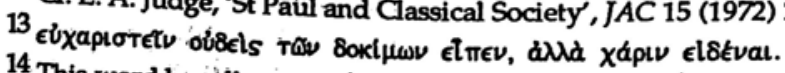

14 This word he calls mapbv '('repulsive').
}

15 This is mapailoyov, perhaps 'anomalous', 'abnormal'. He allows ḱpiov or kopl8ıv or koplom. Cf. MGk koplTol.

${ }^{16}$ The objection here is to the derivatives of the present stem in the sense of the perfect Eүptryopa.

${ }^{17}$ The approved liet is absent from the NT, though $U \in T \delta S$ (5 times, once with the verb $\beta \rho \epsilon \chi \in v \nu$, Rev. 11:6) prevails over $\beta \rho \circ \chi$ ' (only Mt. 5:25, 27). The classical verb would in any case have tended to ambiguity with itacistic changes in pronunciation.

18 A word of much interest and uncertain origin, surprisingly frequent in the LXX, and occurring in the NT only in OT citations. See my note in NovT 24 (1982) 121-3. Cf. MGk Bourb.

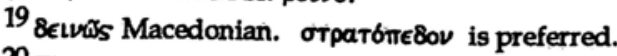

${ }^{20}$ This usage (esp. drokpl $\theta \in i s$, dimekplin) is extremely common in the NT, where 
While such examples give very interesting insights, it seems clear enough that they represent in the main an artificial ideal, contrary at many points to prevailing changes in the current language, where differing levels of style even within the New Testament often concur with the documents against Phrynichus and his like. There are of course many other kinds of social distinction in linguistic usage. A very interesting case is the question of the difference between men's language and women's language. While important studies have been made of this phenomenon in certain tribal and other languages, little attention has been paid to its application to Greek, and then only in general terms which reproduce opinions expressed parenthetically by (male) ancient authors. ${ }^{21}$ There' is scant evidence of actual lexical divergence, though the relative frequency even of common words is likely to have varied markedly as this and other social factors influenced the content of speech.

\section{Borrowings}

The sharp traditional division between Greek and barbarian may go far to disguise the extent to which the Greek vocabulary is indebted to alien sources. The phenomenon may be broadly illustrated in areas other than those where it has attracted the attention of New Testament scholars, in Septuagintalisms or the hypothesis of a 'Jewish-Greek dialect'. It is of interest to consider the occasions for borrowing, when for instance Greek needs a word for an alien concept or institution. There are even cases

the overwhelming majority of about 249 occurrences (according to J. B. Smith's Greek-English Concordance ) are aorist passives (see Moulton and Geden). For the middle form however see Mt. 27:12 = Mk. 14:61 = Lk. 23:9; Lk. 3:16; Jn. 5:17, 19; Acts 3:12.

21 See especially O. Jespersen, Language. Its Nature, Development and Origin (London, George Allen and Unwin 1959 [1922]) 236-54. For the classical languages see B. Newhall, 'Women's Speech in Classical Literature', TAPA 26 (1895), Proceedings of Special Seminars, xxxx-xxxi; M. E. Gilleland, Female Speech in Greek and Latin', AJP 101 (1980) 180-3. Reliable conclusions cannot be drawn from the speech of female characters in drama or in Lucianic dialogue. Among the orators only Lysias introduces women in his speeches and some corroboration of feminine tendencies has been seen in Oration 32. Among the characteristics noticed are (1) discontinuity and lack of logical sequence; (2) linguistic conservatism; (3) pathos; (4) the use of distinctive oaths. I have not seen M. R. Key, Male/Female Language, with a Comprehensive Bibliography (Metuchen, New Jersey 1975). 
where the documents have preserved both a unique Greek borrowing and the original word in the indigenous language, both alike being unknown to the literary sources. Thus we have in Greek $\mu$ lvois for a Lycian society of trustees for protecting a tomb (TAM 2.62, of Telmessus, n.d.) and $\mu \epsilon \nu \delta i T a$ for its members (TAM 2.40, Telmessus, n.d.), beside Lycian minti (TAM 1.2, 4, Telmessus; etc); kaúєıs for 'priestess' in a number of Greek inscriptions of Sardis ${ }^{22}$ beside the Lydian kavés ('priest'),23 a.word which now also explains the previously obscure kaims in a fragment of Hipponax. ${ }^{24}$ Traditional classical Greek contains the well-known Persian words

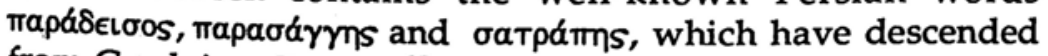
from Greek into English. ${ }^{25}$. There may be a Lydian origin for

221

IGRR 4: 1755; and the long series of dedicatory inscriptions to priestesses,

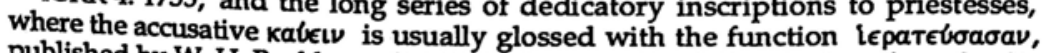
published by W. H. Buckler and D. M. Robinson, 'Greek Inscriptions from Sardis III, AJA 2nd ser. 17 (1913) 353-62, with discussion of the word on pp. 362-8. The word seems to be known only in the accusative, and on the assumption that its form has been Hellenized the - $\eta s$ ending is inferred as the masculine corresponding to the feminine-( $\epsilon)$ is. Thus Hipponax. Testimonia et Fragmenta, ed. H. Degani (Leipzig, Teubner 1983) frag. 3.1 . This 6 th cent. BC satirical poet I am known for his introduction of Lydian and Phrygian words into Greek verse. I am very doubtful about the many other etymological connections suggested by link with Robinson, including the hypothesis (which they do not favour) of a Languages in Cow New York 1953).

23

The Lydian texts, as well as the Lycian and Phrygian, are conveniently 1932), Lydische Friedrich, Kleinasiatische Sprachdenkmäler (Berlin, W. de Gruyter 1932), 'Lydische Texte', 108-23. Few of these documents are datable in more than period (where the famous Lydian are apparently not later than the Persian Artaxerxes), though the survival of thamaic bilingual mentions an unspecified Lycian border of the survival of the language is attested at Cibyra, near the Christian era (Sof Phrygia, after its demise in Lydia proper, at the turn of the Phrygian texts numbering of the Lycian the Roman Imperial period, 2nd - 3rd cent. AD. The kaves see Friedrich 118, nragments is the same in Friedrich as in TAM 1 . For all also of Sardis.

${ }^{24}$ See n.22 above. Evidence of this kind might be greatly extended. Cf. A. H. Sayce, 'Greek Etymologies', CR 36 (1922) 19 (including kaUts ), 164; Sayce, 'Lydian words in the Anthology and Hesychius', CR 39 (1925) 159. Glosses from these and other languages and from dialects of different parts of the Greek world are collected in Hesychius and other ancient lexicographers, and known words from the individual languages have been assembled in modern publications, e.g. Deeters in $R E 13.2$ (1927) 22 for Lycian, A. H. Sayce in Transactions of the Society for Biblical Archaeology 9 (1886-7) 116-20 for Carian. ${ }^{25}$ All are familiar from Xenophon; rapaøáryms occurs as early as Herodotus, as

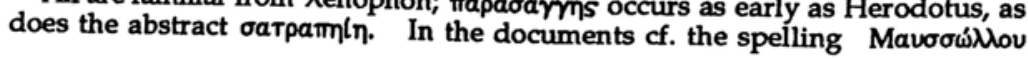


$\kappa d m \lambda \lambda$ os and the word includes the characteristic Lydian - $\lambda$ suffix, whence kamile $\epsilon_{\epsilon \iota \nu}$ in 2 Cor 2:17. ${ }^{26}$ And there is even a supposed Hebrew borrowing in a Jewish Greek inscription from

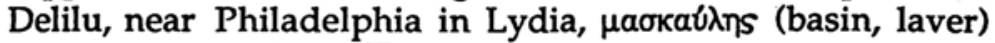
beside Rabbinic ארִ 27

\section{Semantic Interference}

This case is different in one significant respect from what $I$ have classified as the influence of a substratal language, in that there the problem is caused by an imperfect grasp of the receptor language, whereas here even a competent translator may be forced to use an inexact verbal equivalent, which carries over a concept originating in a different tongue, and not precisely expressible by a corresponding word in its new environment. Diverse instances may be included under this heading, which raises some interesting and far-reaching issues. We should normally expect a word to carry meaning in the language in which it is actually expressed, and where the usage seems to be unduly coloured by a different idiom, we may be on the track of a possible technical term. The influence of the Septuagint on the New Testament may be a case in point. ${ }^{28}$

Ekaı (CIG 2691 2, d2, e2; of Mylasa in Caria, 4th cent. BC). Plato in Cratylus 35.410A has Socrates claim that mop (said to be almost identical in Phrygian), B8wp, KiwW and many others were foreign words.

26 According to Herodotus 1:94 the Lydians were the first nation to sell goods by retail, but he does not actually ascribe this word to them. With the ending cf., however, such borrowings and glosses as paktias (?priest-eunuch, Anth.Graec 7.709), kEp $\mu_{1} \lambda$ os (copper-ore, Hesychius), cited by Sayce in CR 39 (1925) 159. This ' 1 '-suffix has been taken as substantiating the traditional relationship betwen Lydian and Etruscan (cf. Hdt, 1.94), and as reflected in the Latin adjectival suffix in facilis, humilis, etc.

27 CJ 754, a dedication to the synagogue by a man designated $\theta \varepsilon \circ \sigma \epsilon \beta$ ts , ascribed by A. Deissmann ( $L A E 452$ n.) to the 3 rd cent.AD. The imperfect transcriptions of the original word in $L S$, and $C J$ seem not to be traceable in the lexica. I am indebted to Mr Philip Jenson for tracing the correct form, for which the locus classicus seems to be TBShabbath $77 a$, where kלtw is given a folketymology, 'washing everyone' (see M. Jastrow, A Dictionary of the Targumim, the Talmud Babli and Yerushalmi, and the Midrashic Literature (New York, The Judaica Press 1982). This explanation is however less compelling from this than from the apparently false LSJ maskol.

28 For fuller discussion of this very complex phenomenon see M. Silva, 'Semantic Borrowing' NTS 22 (1976) 104-10. The study of the Septuagint here presents special difficulties. The version is beset by such textual problems and 
Examples of the phenomenon are very numerous, and mostly unremarkable. Thus it has recently been argued that in Greek sources with a Persian reference the word ofkos stands for more than the king's 'palace' or 'household'. It renders a Persian term which denotes the whole palace administrative system. ${ }^{29}$ Epigraphical instances must doubtless be far more numerous than we can easily identify, for want of knowledge of the semantic fields of the words in the substratal languages. We may suspect, for instance, that when the word tary is used in a unique sense, 'fine', 'penalty', in the text which also contained the Lycian borrowing $\mu \epsilon \nu \delta$ ital (TAM 2.40), that this word was perhaps a semantic loan. Moisés Silva gives the New Testament examples where $\theta \dot{a} \lambda a \sigma \sigma \alpha$ and äpтos are respectively enlarged by writers of Semitic background to cover the sense of $\lambda\{\mu \nu \eta$ and $\beta \rho \tilde{}$ \%ัrs, where the Greek words have a more restricted semantic field. ${ }^{30}$

internal diversity that it is hard for the non-specialist to venture. Some examination of Hatch and Redpath will quickly reveal intractable problems. I have noted for instance that the contested words akakos and mavoupyla are used in curiously inverted senses in the LXX of Proverbs where the former bears a bad sense ('simple', 'lacking in godly wisdom') and the latter a good sense, of 'prudence born of experience', both strikingly different from the regular use of these words elsewhere in Greek, including the Jewish and/or Alexandrian Greek of Josephus, Philo and the papyri. It is not clear that the phenomena of Greek words are imantic borrowing will easily explain these instances, for (i) the in Jos. 9:4; Job 5:12 perfectly aligned with their Hebrew originals, as for instance

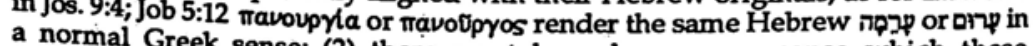
renderings were sense; (2) there must have been some sense which these contradict intelligibled to convey as Greek - though they seem actually to contradict intelligible Greek usage; (3) the difficulty was evidently felt in antiquity, in the tendency to alter the text from akcakos actually to kakós (Prov. in a literalistic kind this disposes of the probable factor of semantic interference in a literalistic kind of translation, but points to a semantic confusion so needed to tell the whole a more sophisticated kind of explanation appears to be peculiarly open to dele story. Perhaps value-words in areas like 'cleverness' are antithetical reversal.

29 A. Treloar, Persian olkos', Prudentia 17 (1985) 107-9.

30 M. Silva, NTS 22 (1976) 104, 108. These instances belong to Silva's fourth category of 'unconscious loans'. It is of interest here to note the classification he offers: (1) words whose frequency is influenced by Semitic background (e.g.
dros); (2) doubtulul Aramaisms, whose Semitic equivalent is not established; (3)
loans 'doubtful' for a differis loans 'doubtful' for a different reason, as it is not clear whether the phenomena are due to an attested Semitic parallel or to semantic change within Greek; (4)

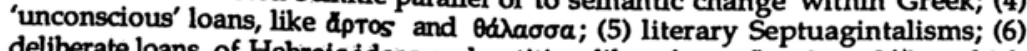

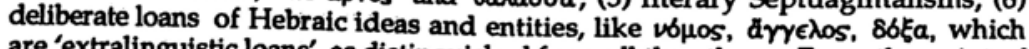
are 'extralinguistic loans', as distinguished from all the others. From the point of view of technical theological language (see below) this group is of particular 
Some cases in this category are of much greater theological weight. It is widely conceded that in the New

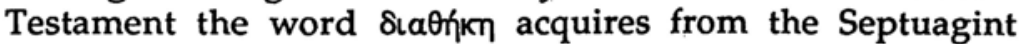
rendering of Hebrew Greek literary and documentary sense of 'will', 'testament', as also from ouv $\theta$ ifkn ('agreement', 'compact'). ${ }^{31}$

\section{Varieties of Formulation}

This category again comprises very diverse phenomena. A simple and trivial case is the alternation on tombstones between

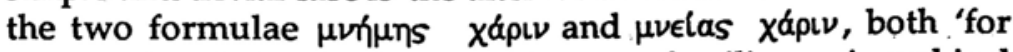
memory's sake'. I choose this very familiar epigraphical example as a case of quite random synonymity. One or other of these tags concludes thousands of sepulchral texts. There may be at most some statistical diversity in frequency in different times and places. ${ }^{32}$ Very different is the remarkable proliferation of local terms for tombs (or for types of tombs). Louis Robert mentions for instance oT $\_\beta$ d́s in western Caria, mupia, peculiar to Teos, Colophon, Ephesus and the Cayster valley, and goes on to infer that EvTouls on a stone copied in Istanbul was sufficient ground for assigning its origin to Thessalonica, where alone this term is otherwise attested. ${ }^{33}$ Of

significance.

31 Cf., however, Aristophanes, Birds $\mathbf{4 4 0}$ for a sense of the word more nearly

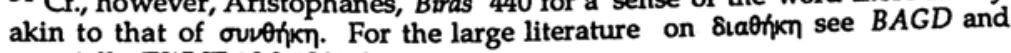
especially TWNT 10.2.1041-6.

32 I have a general impression that $\mu \nu \epsilon l a$ is relatively more frequent in Macedonia, whereas $\mu \nu \eta \mu \eta$ is overwhelmingly dominant in Asia Minor. But such impressions are subject to statistical and chronological analysis, which might provide a different, or more complex, picture. Note, however, that both words are freely available synonyms (and so in the NT, cf. $\mu v \in$ la in Rom 1:9 with $\mu \nu \mu_{\mu} \eta$ in 2 Pet 1:15), though not coincident in their semantic fields across the range of other contexts. Today a Turk likes his coffee çok şekerli ('very sugary'), a Turkish Cypriot çok tatlı ('very sweet'). Both words are freely available to both groups, but a difference of custom has become formalized in the speech of the two territories.

33 L. Robert, Études Épigraphiques et philologiques (Bibliothèque de l'Ecole des Hautes Etudes 272; Paris, Champion 1938) 219. Robert observes that the Greek epigraphist S. Pelekides had collected four examples of Evropis, all from Thessalonica, to which Robert adds a fifth from the same city, apart from the present instance. In a quick search of IG 9.2.1, I found ten, all from Thessalonica and all from about 2 nd - 3rd cent. AD: $\boldsymbol{G}$ 9.2.1.308, 470, 478, 500, 586, 621, 745 $815,824,831$. Likewise the occurrence of $\lambda a r b \mu l(0) \nu$ as a term for tomb serves as ground for assigning another transported stone in Istanbul to the neighbourhooc 
more direct and familiar interest is the variety of titles for local officials, a matter reflecting in part differences of local function and constitution, in part local dialect or local fashion, in part perhaps a mere accident of formulation in the choice between synonyms. The well-known accuracies of Luke, moגıтd́pxal at

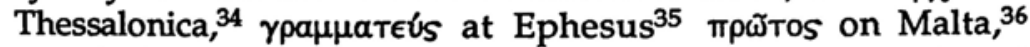
and the like, may be set within a much wider canvas, with such less familiar cases as tayol in Thessaly ${ }^{37}$ and $\kappa 6 \sigma \mu o l$, with its own variations and derivatives and its dialectal variant $\kappa 6 \rho \mu \circ$, in different cities of Crete. ${ }^{38}$ Different again is the intriguing fact that people in different cultures actually say different things in what might be deemed comparable situations. I doubt if we should render the formula $\varepsilon T\{\mu \eta \sigma \epsilon \nu$ in inscriptions otherwise than as 'he honoured'. But it strikes me that our cultural equivalent is rather 'congratulate' than 'honour'. That is how we might demythologize another's language. But the content is of Perinthus in Thrace (Robert 221).

34 Attestations of this word from Thessalonica and other Macedonian cities are now numerous. E. de W. Burton, 'The Politarchs' ATT 2 (1898) 598-632, though still commonly cited, is very dated. See now C. Schuler, 'The Macedonian Politarchs', CP 55 (1960) 90-100; F. Gschnitzer, $R E$ Supp 13 (1973) 481-500; G. H. R. Horsley, New Docs 2 (1977/1982) no. 5 34-5; and literature there cited. Horsley dites this word as a case in point where the $M M$ and $B A G D$ entries need revision. The latter, published in 1979, 'has not gone beyond the $1890 \mathrm{~s}$ and MM in its references to secondary literature' (New Docs 2.35).

35

This term is attested passim in the inscriptions. See now the seven volume corpus Die Inschriften oon Ephesus, ed. H. Wankel (Bonn, Rudolf Habelt 197981) in the series Inschriften griechischen Stadte aus Kleinasien. This is one specialized use of a more widespread word, used of city officials elsewhere also, as at Athens, though not necessarily in precisely similar senses or for persons with the same function. The special NT usage ( $=$ 'scribe), while itself an instance of semantic borrowing (cf. Silva NTS 22 [1976] 109), functions as one more of the many special applications of the word.

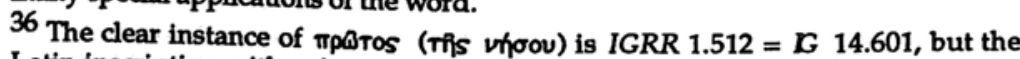
Latin inscription with primus, often cited in support (Cll 10.7495.1), may refer to its honoree merely as 'first' to perform various benefactions, an interpretation consistent with the fragments of its mutilated context.

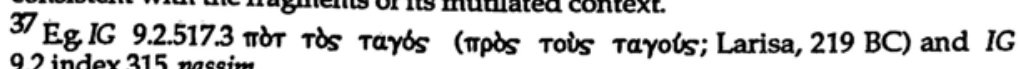
9.2 index 315 passim.

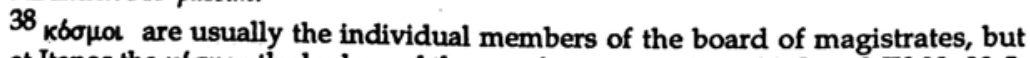

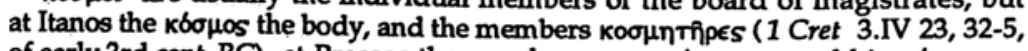

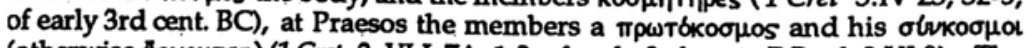
(otherwise apxovtes) (1 Cret 3. VLI. 7A. 1-3, of early 3rd cent. BC; cf. 3.VI.9). The dialectal variant koppos appears, rather strangely in the later texts of the Roman

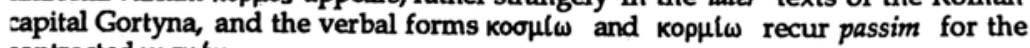

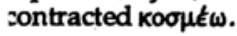


different. We do not normally 'celebrate' a good degree by cutting a student's name on stone, to say no more.

\section{Choice of Synonyms}

The same kinds of phenomena are seen, not only in formal titles, but also in a broad spectrum of individual preferences, statistical variation between the frequency of synonyms, ${ }^{39}$ diachronic shifts of fashion even between common words, and the like. It strikes me that it is very difficult at our distance in time to analyze precisely the limits of the semantic fields of ancient words of any particular time and place, and that a very important function of a future lexicon must be the discrimination of synonyms and near-synonyms. Vocabulary is, I suspect, hugely affected by very slight stimuli, small shifts of tone or content or individual idiosyncrasy, or the subconscious tendency to the repetition of mannerisms. Such things may produce bewildering statistical oddities which have little or no stylistic significance, especially in documents so brief as most of the New Testament writings. ${ }^{40}$

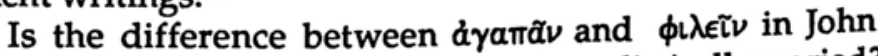
21:15-17 semantically significant or only stylistically varied? There are good scholars on both sides of the argument. 41 The answer, it seems to me, lies in much more detailed analysis of

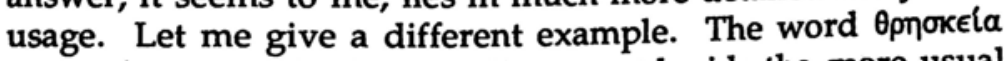
occurs four times in the New Testament beside the more usual $\epsilon \dot{\sigma} \sigma \in \beta \epsilon \iota \alpha$, and as a 'religious' word, denoting religious worship

39 Cf. Silva's second category, n. 30 above. The phenomenon is not, however, confined to instances of semantic interference. I should suggest that a large element in the distinction between two idiolects resides in the unequal frequency and status of words belonging to the recognition vocabulary and perhaps even to the speaking and writing vocabulary of both, if in markedly different extent.

40 A remarkable instance is that of the occurrence of $\tau \epsilon$ in the Lukan writings, eight times in the Third Gospel and about 158 times in Acts, and $T \epsilon$ apart from kal never in the Gospel, but about 99 times in Acts. Yet few have been persuaded by this anomaly to posit a difference of authorship between the two works. On the problems of using statistics as a criterion of style and authorship cf. L. F. Clark, An Investigation of some Applications of Quantitative Methods to the Pauline Letters, with a view to the question of authorship (unpublished MA dissertation, Manchester 1979).

41 Against reading subtle distinctions into these usages see e.g. J. Moffatt, Love in the New Testament (London, Hodder 1929) 46; C. C. Tarelli, JTS n.s. 1 (1950) 67. In favour of seeing significance in the change of verb see C. Spicq, Agape dans le Nouveau Testament 3 (Paris, Gabalda 1959) 232-7. 
or service, seems a very proper object for our inquiry. 42 It has sometimes been suggested that $\theta$ p

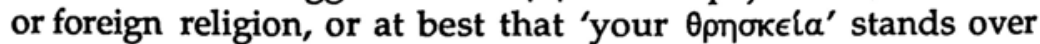
against 'my $\epsilon \dot{U} \sigma \epsilon \in \epsilon \alpha^{\prime}$ '. But Louis Robert has set out all the epigraphical occurrences he knew of the word, as part of a contribution towards a lexicon of the inscriptions. ${ }^{43}$ He finds

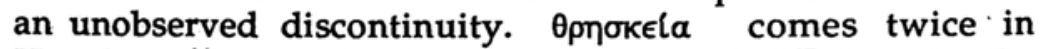
Herodotus, ${ }^{44}$ never in the Hellenistic period ${ }^{45}$ (nor in the canonical books of the Septuagint) ${ }^{46}$ but reappears as a common word in the Koine from the mid first century BC. It seems most likely to have been an Ionicism, which found its way relatively late into the mainstream. Further, while it is true that it is frequently used in pejorative contexts, there is nothing in the semantic content of the word to require this. This is an important point, for there is a recurring tendency in theological lexicography to want to accumulate connotations which are imported only from particular contexts. James Barr is right in his criticism of such 'cumulative semantics'.47 The word is used, as Robert shows, in a pretty consistent way by pagan, Jew and Christian, although they will all doubtless festoon it with different contextual associations. But the diachronic factor looks to be significant here in considering the availability of synonyms, and this element in the analysis is quite omitted, for instance, by 42 Acts 26:5; Col. 2:18; James 1:26, 27. In Acts Paul refers to his own (Jewish) religion; in Colossians the context is adverse, of angel-worship; James contrasts vain 'religion' with that which is pure and undefiled. The word itself in these instances is neutral, acquiring connotations from its context and object.

43 L. Robert, Etudes epigraphiques et philologiques 226-35, citing a Dutch writer J.van Herten. IGRR 4.1381.4 (Coloe, Lydia; 3rd cent. AD) is an example of the kind of context which lends itself to a notion of 'foreign cult'; but contrast e.g. OGIS 595.9 (Puteoli, AD 174-5). The semantic content of the word must, however, be carefully distinguished from its external associations in one type of context.

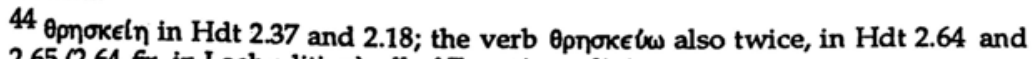
2.65 (2.64 fin in Loeb edition), all of Egyptian religion.

45 Robert (233) shows that the supposed Hellenistic attestation of the 3rd cent. BC (IG 12.5.141, of. Paros) derives from a misprint, where ' $a$.C!' (ante Christum ) should read ' $p . C$. ' ( post Christum ), the text exhibiting ligatures and persons with praenomen 'Aurelius'.

46 It is used in Wis. Sol. 14:18, 27; 4 Macc. 5:7; and the verb in Wis. Sol. 11:16; 14:16; in 4 Macc. it is Antiochus' word for Jewish religion, in Wis. Sol. it is applied to idolatry. These books are, however, so late as not to constitute exceptions.

47 J. Barr, The Semantics of Biblical Language 218, 222 uses the expression 'illegitimate totality transfer'. 
K. L. Schmidt in TWNT, whose treatment is otherwise open to Barr's strictures. 48

\section{Technical Terms}

These considerations are very relevant to a point of focal interest, technical terminology, and in particular theological language. In his very interesting lecture last year on technical terms in Hebrew, Roger Cowley asked for reliable criteria by which such technical usage could be identified. ${ }^{49}$ The words claimed as technical included, for instance, some of the very common and some of the very rare, some of the ostensibly theological and some of the ostensibly mundane. A comparable question may be raised in the New Testament field, whether for instance there are clear criteria, other than a judgement of the interests of likeminded theologians, which direct the larger or smaller selections of words treated by Kittel, or Turner, or Spicq, or NIDNTT . It is apparent, for instance, that a hapax legomenon known only from biblical Greek is not thereby proved a 'biblical' word, unless we can establish some probability that Jews or Christians chose or coined it for some reason and that alternative explanations are far less probable or viable. Thus a word like áyám gives much food for thought. But there is often a converse argument, that Christians took current vocabulary in senses essentially current, and those words became enriched in their associations by the new contexts in which they were used. It is exceedingly difficult to say where the semantic content of the word first took on a specially Christian flavour apart from context. Thus examples are hard to specify. The other categories may in fact help to outline a framework for assessing this crucial one. We may incline favourably to the inclusion of $\delta a \theta t i k n$ or $\dot{a} \gamma \dot{\alpha} m \eta$, where there is a strong Septuagintal background or an apparent discontinuity with secular usage. But the mlotis wordgroup, for instance, is not so clear. Despite C. Gilmour's impressive recent study of the history of these words from Homer to the Christian era, ${ }^{50}$ I am not sure that the first

48 K. L. Schmidt TDNT 3.155-9. Cf. Barr's treatment of Bauer's 'external lexicography' in his treatment of miorts as a word for 'religion', a discussion in which Opnorela figures incidentally. The word occurs some 92 times in Josephus, often of Jewish faith, and five times in Philo, in one place in opposition to

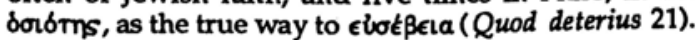

${ }^{49}$ R. W. Cowley, 'Technical Terms in Biblical Hebrew?', TynB 37 (1986) 21-8. 
Christians can be shown to have done much more than use some of the semantic resources of the group with an unusual frequency and characteristic focus dictated by the subject-matter of their gospel. It is perhaps only when mi $\sigma$ TLs serves as an insider's shorthand for 'the body of Christian belief' as in Jude 3, that we get a stronger hint of a private jargon. But even that has a possible parallel in an earlier source (Diod. Sic. 1.23.8, of 1st century $B C$ ), and I am not sure that I see greater linguistic significance in such developments than in other kinds of semantic shift included among the examples we have been discussing. But the evaluation of such matters belongs to a much more systematic and analytical semantic study, exploring fields of synonymity and opposition, a study differently focused from the present desultory comments. 51

$50 \mathrm{C}$. Gilmour, The Development of the Language of Faith. A Historical Survey', Prudentia 17 (1985) 55-70. I should not attach special significance to morew $\mathrm{el} s$ as a Christian innovation (a point stressed by R. Bultmann in TDNT $6.203-4$ as a formulation of the language of mission).

51 It ought to be possible to list actual criteria for the recognition of technical language in the NT, but to date the question has proved to be elusive. It may be part of the answer to Cowley's dilemma that quite different categories of words need to be considered as candidates, and upon quite different kinds of criteria, and even these categories will differ from those which might be applicable to the OT. Further, the criteria must be strict if they are to give significant results, perhaps too strict to produce much result at all, an outcome which may fail to be representatively accurate if a lot of the 'big fish' get away for lack of a sufficiently inclusive net.

Three very different types of word may be offered for consideration: (1) vernacular words which have become characteristic of a closed group which uses them in a private sense; (2) words enshrining Semitic ideas, used in a sense different from their ordinary Greek meanings, a conscious form of semantic borrowing (cf. Silva's sixth category); (3) religious words which appear to be hapax legomena or new coinages.

In the first type there can be no rigid line marking the point in a continuum where a vernacular word moves from being specially frequent or characteristic in an idiolectic group to the place where it becomes an item of private jargon. It may be suggestive, but insufficient, to ask whether its 'private' sense is unparalleled in secular Greek - insufficient, for if it is little more than an extension of an existing meaning, this phenomenon is extremely common in a language rich in metonymy, where common words have innumerable special applications which are not necessarily 'technically' significant. It may be a strong point if the word is made to stand as a shorthand term for a larger content than it expresses semantically, as with $i$ in 8865 in Acts 9:2.

The third type also calls for brief comment. It has been a tendency to build uncritically on the special significance of unique words. But it is doubtful if we should attach weight to them unless (a) they carry distinctive religious meaning; (b) they are not explicable as derivatives or compounds of words with wider secular currency; and (c) there is some evidence or intrinsic probability that the 
I propose to illustrate the foregoing categories with two more extended examples which involve topics of social and religious interest, both raised primarily by the inscriptions of a distinctive district of NE Lydia, the evidence for which has been greatly enlarged by recent publications, and a large body of new material collected especially in the most recent fascicle of TAM. $^{52}$ The first topic is not directly applicable to the New Testament, but illustrates problems of method and interpretation; the second is much more immediate in its implications.

\section{KINSHIP TERMS IN LYDIA}

The new texts greatly augment the number of epitaphs of the district where the relationships to the deceased of all the members of an extended family are spelled out with unusual precision. Some of the terms used are unique, or paralleled only in adjoining parts of Phrygia, or at least rare in literature, if not wholly absent from it. ${ }^{53}$ Sometimes the relationship is even

early church should have needed or wished to create them. Greek, unlike British English, is very fertile in word-creation, and new documentary texts are continually adding rapidly to the Greek lexicon, often new derivatives and compounds of known words, and such additions are found even in texts of 'pure', correct language.

The topics treated here are samples of kinds of variation. It would be easy to add other types: (1) variations in the semantic fields of synonyms in different forms of a language, where e.g. American 'sauce' includes what the British call 'gravy', 'custard', and occasionally other words; (2) refinements in the application of place-names, an important and neglected area of ancient lexicography; (3) differences in the syntactical form of expression between languages or their varieties, where, e.g. English tends to use a place name 'Ephesus' where Greek thinks of a people 'the Ephesians', or where English will predicate an office or function of a person in a substantival form, Greek very commonly with a verb (үранцатє $(\in t v$, etc).

52 Tituli Asiae Minoris vol. 5 'Tituli Lydiae', fasc. 1 'Regio Septentrionalis ad orientem vergens', ed. P. Herrmann (Vienna, Austrian Academy of Sciences 1981).

53 The terms discussed here are only a brief sample. A fuller list from this

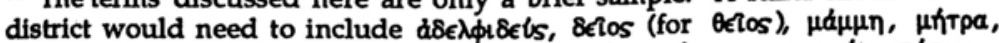

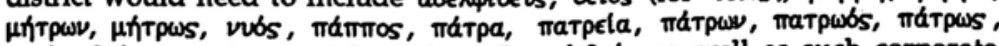

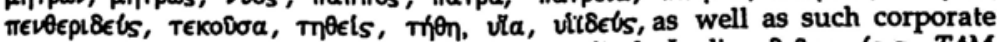

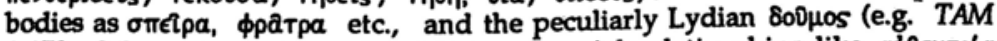
$5.470 \mathrm{a} 8-9$, of Ayazviran, AD 96-7) and social relationships like aivevtpla,

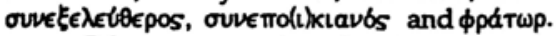

Other rare or unique kinship terms are found elsewhere in Asia Minor. In casual reading I have noted $\pi \rho \delta \mu a l a$ ('great grandmother') at Caunus in Caria, a Doricism probably reflecting Rhodian occupation in 1st cent. BC (G. E. Bean in 
specified reciprocally: î $\mu \not \alpha \mu \mu \eta$ Tò $\kappa a ́ \mu \beta \epsilon \iota \nu$, which must be 'grandmother to grandchild' (TAM 5.706, of Julia Gordos, AD 47-8), though the latter word is unique, first listed in LSJ Supp., and only doubtfully paralleled by forms found recorded epigraphically at Didyma, Ceramus and Iasos, all near the coasts of Ionia-Coria, and now also at Saittae, in the same part of Lydia. ${ }^{54}$

The more interesting terms, however, are those which appear to reflect a different social structure which makes distinctions usually unmarked in other varieties of Greek. Thus while $\gamma \alpha \mu \beta \rho b s$, fem. $\gamma \alpha \mu \beta \rho \alpha$, is common, not least in the epigraphy of Anatolia, for different relations by marriage, we have here a much more elaborate set of terms. Thus from the wife's perspective her $\delta a$ in is her husband's brother, ${ }^{55} \gamma \alpha \hat{\prime} \omega s$ her

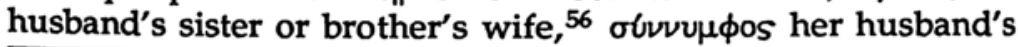

JHS 73 [1953] 34, no. 19, noted only in LSJ Supp ); mıbarpa (perhaps 'father's sister'; IHS 25 [1905] 174, Isaura; but the example offered in PASA 3 [1884-5]

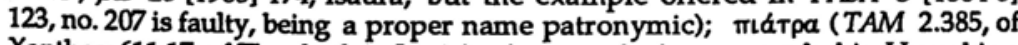
Xanthos; 611.17, of Tlos, both in Lycia). vtvvos and vávvn, recorded in Hesychius, appear to relate to an Asianic root widespread in the Greek documents. In one variant it has been connected with Lycian nênt (maternal aunt/uncle; E. H. Sturtevant, 'Some Nouns of Relationship in Lycian and Hittite', TAPA 59 [1928] 48-56), and one may wonder whether it has passed into modern Turkish nine ('grandmother'). I have also found vivm in two texts from Thessalonica ( $G$ 9.2.1.510, of 2nd or 3rd cent. AD; 624, of AD 125-6), and LSJ cite this form only from the same city. All these variants designate an elder relative. Most are

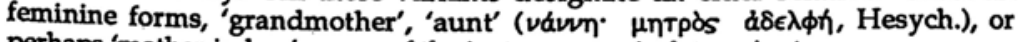
perhaps 'mother-in-law': many of the instances are indeterminate.

54 The normalized orthography would presumably be $\kappa \dot{\alpha} \mu \beta\llcorner o v, ~ \iota$ (even when short) becoming interchangeable with $\epsilon \mathrm{L}$ in later inscriptions, and the of the neuter diminutive termination often being lost, whence e.g. feminine personal

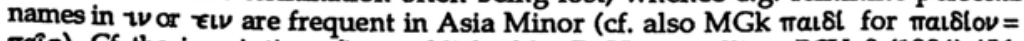
mais). Cf. the inscriptions first published by B. Haussoullier, BCH 8 (1884) 456,

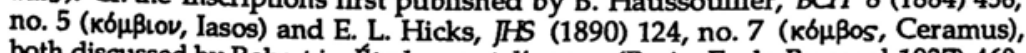
both discussed by Robert in Études anatoliennes (Paris, E. de Boccard 1937) 46971 and in Hellenica 6 (Paris, Adrien-Maisonneuve 1948) 95-8. The reference to Didyma, 'Die Inschriften', ed. T. Wiegand (Berlin, A. Rehm 1958) 349-4 seems to be incorrect. Cf. now also kávßetos in H. Malay and Y. Gül, ZPE 44 (1981) 86, no. 12 (Saittae, AD 189-90).

55 8anp: TAM 5.472 (Ayazviran, AD 144-5), 483a (ibid., n.d.), 660 (Daldis, n.d.), 680 (Characipolis, AD 129-30), 704 (Julia Gordus, AD 75-6), 707 (ibid., AD 70-1), 725 (ibid., AD 153-4), 733 (ibid., AD 188-9), 764 (ibid., AD 171-2), 782 (Yayakunldik, AD 120-1), 810, 811 (Dagdereköy, n.d.). The brief LS entry does

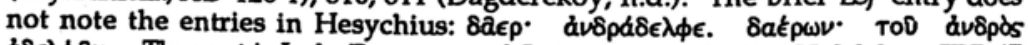
$d \delta \varepsilon \lambda \phi a v$. The root is Indo-European: cf. Latin levir. Cf. also H. Malay, ZPE 47 (1982) 113, no. 2 (Saittae, AD 189-90).

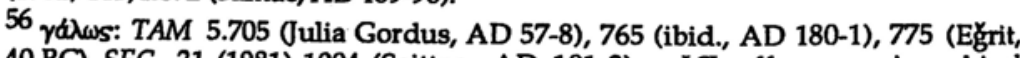
40 BC), SEG 31 (1981) 1004 (Saittae, AD 101-2). LS offer no epigraphical 
brother's wife. ${ }^{57} \mathrm{~A}$ term of particular interest is the newly confirmed lavárnp (brother's wife), ${ }^{58}$ also occurring as kvámp $\rho$, a form paralleled only in Phrygia. ${ }^{59}$ The usual local form of this word is quite unknown to the lexica.

This is where the plot begins to thicken. Some of these words are otherwise attested mainly or only in the Iliad, almost a thousand years earlier than our texts of the first to the third centuries $\mathrm{AD}$. The most interesting passage is $I l$ 24.768-70:

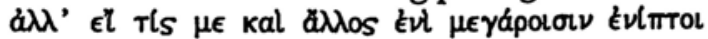

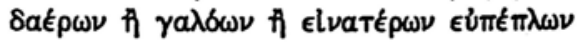

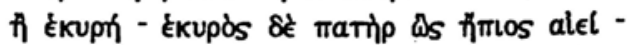

The latter two lines contain counterparts of no fewer than five words otherwise almost peculiar to our Lydian epitaphs: $\delta a \eta$,

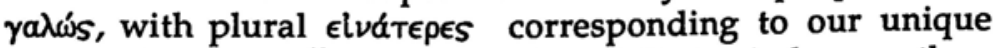

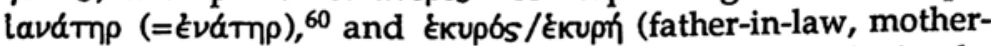
in-law), which appear in our inscriptions regularly in the

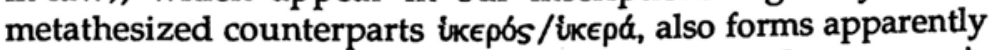
unique to the inscriptions of this district, though common in them. ${ }^{61}$

references at all, nor any instance outside the lliad and the grammarian Herodian (2nd cent. AD) and the Etymologicum Magnum. Hesychius defines both ralows

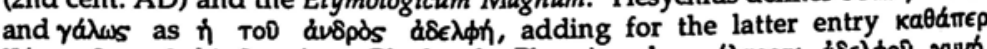

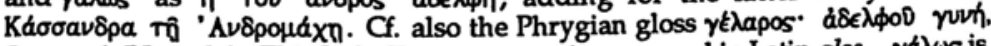

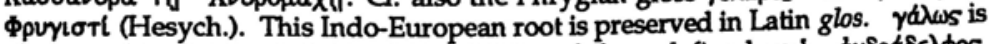

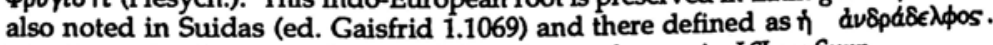
The alternative form yalowinn noted there is not taken up in LS or Supp .

57 olvvıuфos: TAM 5.775 (Egrit, $40 \mathrm{BC}$ ).

58 lavámp: TAM 5.682 (Characipolis, AD 161-2), 754 (Julia Gordus, n.d.), 775 (ibid., 46-5 BC); possibly also 412 (Collyda, n.d.) and 703 (Julia Gordus n.d.), which depend on uncertain restorations.

59 kvármp: TAM 5.782 (Yayakirildik, AD 120-1). Also SEG 28 (1978) 1096. (Altentas, Phrygia), a Christian text, which also has 8 atp. The dative there reads EvạTpl.

60 For the combination of $\gamma$ dilows with elvadtepes cf. also 1. 6.378, 383; 22.473. The Homeric word is always plural, but elvámp would be metrically impossible, unless the plural is itself a metrical lengthening for évátepes, from Evámp. It is however clear from the metre that the word began with a digamma. The epigraphical variant kvámp is thus close to the Homeric, but the characteristic Lydian lavámp is anomalous. Hesychius gives two relevant entries, one taking

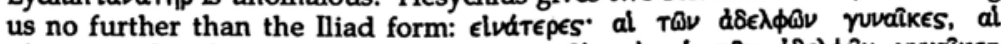

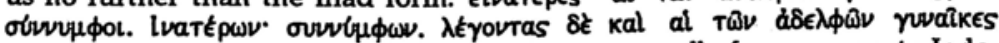
lvátepes. A final twist is the Latin ianitrias, supposedly from a cognate IndoEuropean root, but looking to have been confused or assimilated with the more familiar 'female door-keeper'. The question is then even raised whether the form lavarmp could have been affected by secondary contamination with the Latin, though this is preserved only late, in Isidorus (ed. H. Digent). 
The explanation of this striking discontinuity is unclear. It may be that supposedly rare kinship terms were preserved and even widespread in non-literary Greek, though they surface to our view only in a district where a distinctive social structure and epigraphical style fostered their unusually public and frequent use. It might even be supposed that they are linked with western Anatolian influence on the language of Homer or reflect a continuity or analogy with heroic social structures in Roman Anatolia. Or it may be that here a non-Greek social structure, originally expressed in a non-Greek language, resorted to literary archaism to find Greek equivalents for terms belonging to the native culture. There are possible indications to favour either kind of option. As the forms often differ from the Homeric, and even seem to show dialectal differentiation and development, they look to have indigenous roots, yet some of them attempt to reproduce archaic declensional forms which makes them look also like errant boulders in their environment. ${ }^{62}$ The complexities of the possible interplay of influences here could be carried much further. It is clear only that there is much more here than meets the eye, and that the elaborations here go far beyond the ordinary accounts of Greek kinship language. ${ }^{63}$ A sociolinguistic peculiarity is evidently rooted in a story which lies deeper, and the possibility is raised that some of these rare words had a wider and more continuous currency than our fragmentary attestations permit us to know, like an extensive submarine reef which signals its presence only

61 ikepos: TAM 5.472 (Ayazviran, AD 144-5), 704 (Julia Gordus, AD 74-5), 784 (Yayakarlddik, AD 201-2), 796 (Hamit, AD 129-30), etc.; rarely also kxup6s : 705 (Julia Gordus, AD 57-8). UKepa: TAM 5.765 (Julia Gordus, AD 180-1), etc. These forms are prevalent, and take their own itacistic spellings, clearly based on the usual Lydian form: Lkepós (631, Daldis, 3rd cent. AD); íkaipós (825, Kömürcü, n.d.). LS treat exupos as a distinctively Epic word, though they note epigraphical instances also. Yet the Latin socer is more closely akin to our

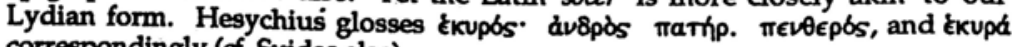
correspondingly (cf. Suidas also).

62 Instances are too few to draw large conclusions, but the 'correct' accusative lavdrepa stands beside ouyatEpav in an identical context in the same text (TAM 5.754), and forms like 8atpa are likewise consistent as against the frequency of

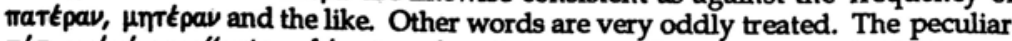

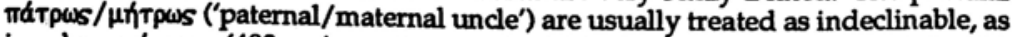
in Tòv márpws (483a, Ayazviran, n.d.; 704, Julia Gordus, AD 75-6; 786,

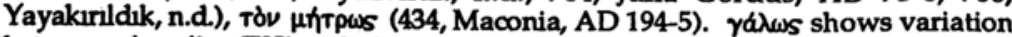

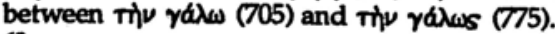

${ }^{63}$ Cf. e.g. M. Miller, 'Greek Kinship Terminology', JHS 73 (1953) 46-52. 
by the rare and widely separated places where it breaks the surface. ${ }^{64}$ And this is a point to bear in mind in our evaluation of New Testament hapax legomena. ${ }^{65}$ The argument from silence here, as in many other contexts, is problematic. Older notions of peculiarly 'biblical' words are often open to criticism here, for there is need to recognize the essentially fragmentary character of our knowledge of this vastly rich linguistic complex. I have argued elsewhere that a unique word in a place so familiar as the 'daily' bread ( $E$ mLotolos $)^{66}$ in the Lord's Prayer is just such an isolated outcrop from a large hidden continuum embedded in the massif of contemporary Greek, and not a theological speciality. Other instances are of course different, but even they need to be described within the totality which includes the idiolect.

\section{PAGAN RELIGIOUS TERMINOLOGY}

The epigraphy of the same district instances also numerous pagan examples of specifically religious words of the kind which we are accustomed to treat as distinctively 'Christian' words. They thus provide an extreme converse approach to the ongoing debate over the nature of New Testament Greek, by giving a different perspective on the main staple of our 'theological'

64 Another case from the same group of documents will illustrate otherwise the limits and discontinuities of our knowledge of the Greek language. Thus 'daughter-in-law' in Homer is vubs (cf. Latin nurus ), which again reappears after an apparent gap in our texts from Lydia, e.g. in the reciprocal ikaipol tô vup (TAM 5.825, n.d.; cf. 703, 779, 795, etc.). But the kotvi word is ordinarily vif $\phi \eta$, whence MGk $v i \phi \eta$. This is the NT form, and it is used both for 'bride' and 'daughter-in-law' alike in secular and biblical Greek (as 'daughter-in-law' in LXX). What however was the Attic form? No word for 'daughter-in-law' seems to be recorded from that period (see G. P. Shipp, Modern Greek Evidence for the Ancient GreekVocabulary [Sydney, UP 1979] 606, n. 122).

A final question touches on the semantics of these words. None of the Homeric contexts are as specific as the inscriptions, and it is unclear whether we may extrapolate from the pattern of relationships contained in them. If there is a real underlying social and linguistic continuity, perhaps we may. If there is a measure of archaistic revival in Lydia, the new applications of the words may not be quite the same. And even if there is continuity, semantic changes may have operated, especially in the application of old words to subtly different social structures. It seems that elvdTepes cannot in any case be 'brother's wife', as in Lydia, for Helen's brothers (II . 24. loc. cit. ) were Castor and Pollux, and not her Trojan in-laws.

65 See $n .51$ above.

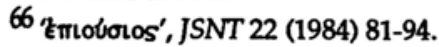


dictionaries. The special value of these texts is that they provide again multiple attestation of the interrelation of concepts in the usage of the same district and even of the same group of cults, of Men Tiamou or Men Axiottenos in the neighbourhood of Coloe (Kula), thus overcoming the methodological pitfall of trying to evolve concepts from a composite of scattered and unintegrated sources. The texts represent the same range of dates as in the kinship terms, form the first to the third centuries $A D$, often dated precisely to the day, and apparently uninfluenced by Christianity, though geographically close to some of its earliest centres in Anatolia. ${ }^{67}$

The texts of particular interest are the 'confession inscriptions' or Sühneinschriften, a type long known, especially from the examples first published by W. M. Ramsay from the shrine of Apollo Lairleuos near Dionysopolis in SW Phrygia, adjacent both to our present corner of Lydia and to the New Testament churches of the Lycus valley. I shall, however, focus here on the more recent proliferation of texts of the Men cult in Lydia. ${ }^{68}$

67 The question of Christian influence cannot be dismissed without consideration, if only because chronology is a significant factor, too often neglected, and because it must be recognized that the more elaborate casehistories which give the theological content are almost all of the 2 nd or 3rd centuries. The districts involved seem, however, to show marked cultural contrasts with the Hellenized cities of the main routes. The environment was more largely rural, where traditional Anatolian cult was strong. There is a high probability of continuity there, as well as of analogy with indigenous cults of similar type throughout Anatolia. It is a generally observable phenomenon that later texts are more explicit and explanatory than was customary in the first century. A 'history of religions' approach would be difficult to pursue here in any direction. The present more limited concern is simply to consider whether the independence of the lexical evidence of the texts might be prejudiced by any adoption of Christian terminology. I think not. There is no sign of polemical response or of influence. The texts are too artlessly expressive of offence and retribution in a localized cult. Their horizons are very narrow.

68 W. M. Ramsay, Cities and Bishoprics of Phrygia I (Oxford, Clarendon Press 1895) 136-8, 149-53 for the Dionysopolis texts. There is a large subsequent literature on texts of this type, including a spate of recent publications of texts from Lydia. See F. Steinleitner, Die Beicht im Zusammenhange mit der sakralen Rechtspflege in der Antike (Leipzig, Dieterich 1913); W. H. Buckler, 'Some Lydian Propitiatory Inscriptions', ABSA 21 (1914-16) 169-83; J. Zingerle, 'Heiliges Recht JOAI 23 (1926) Beiblatt, cols. 5-72; A. Cameron, 'Inscriptions Relating to Sacral Manumissions and Confessions', HTR 32 (1939) 155-79; E. N. Lane, Corpus Monumentorum Religionis Dei Menis (EPROER 19), 4 vols. (Leiden, Brill 1971-8), and 'CMRDM Addenda 1971-81', Second Century 1 (1981) 193-209; P. Herrmann, 'Men, Herr von Axiotta', Studien zur Religion und Kultur Kleinasiens. Festschrift für F. K. Dörner, ed. S. Sahin, E. Schwertheim and J. 
Perhaps I can best introduce these texts and their significance by translating a sample: the Greek is in places so peculiar or unclear that I have felt free to paraphrase slightly, while inevitably leaving obscure some allusions and ambiguities.

Year 241, 2nd day of the month Panemos. Great Artemis Anaeitis and Men Tiamou. Jucundus fell into a state of madness, and it was rumoured by everyone that he had been given a potion by his mother-in-law Tatias. But Tatias placed a sceptre [on the altar] and swore an oath in the temple, defending herself against the rumour while knowing herself to be guilty. The gods inflicted on her punishment [lit. 'did her in punishment'], which she did not escape. Likewise also, her son Socrates, as he was passing the entranœ leading to the sacred grove with a sickle in his hand for cutting vines - it fell from his hand on his foot, and so with double punishment on one day satisfaction was made. Therefore great are the gods in Axitta. They placed the sceptre [on the altar] to resolve the oaths which had been taken in the temple, which the offerings of Jucundus and Moschios resolved, and the descendants of Tatias, Socratea and Moschas and Jucundus and Menecrates, propitiated the gods in all things, and from now we praise them, setting up on this stele our tribute to the wonderful powers of the gods. (CMRDM 1.28-9, no. 44 of AD 156-7 (Ayazviran [?Coresa], near Kula, Lydia).

Without stopping for detailed comment on this very interesting case-history ${ }^{69}$ (where Tatias may well have been innocent, condemned in retrospect by a grim coincidence of accidental - or contrived - fatalities), let us note the naive religious vocabulary of guilt, vengeance and atonement. We have here ouvelonjots,

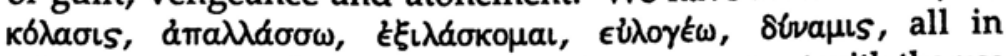
religious senses which invite comparison or contrast with the use

Wagner (EPROER 66) 2 vols. (Leiden, Brill 1978) 1.415-23; G. H. R. Horsley, 'Expiation and the Cult of Men', New Docs 3 (1978/1983) 20-31, no. 6; E. Varnnlioglu, 'Zeus Orkamaneites and the Expiatory Inscriptions', Epigraphica Anatolica 1 (1983) 75-87; P. Frisch, 'Uber die Lydisch-phrygischen Sühneinschriften und die Confessiones von Augustinus', EA 2 (1983) 41-6; P. Herrmann and E. Vannlıoglu, 'Theoi Pereudenoi. Eine Gruppe von Weihunger und Sühneinschriften aus der Katakekaumene', EA 3 (1984) 1-18; H. Malay and G. Petzl, 'Neue Inschriften aus den Museen Manisa, Izmir und Bergama', EA 6 (1985) 55-68; H. Malay, 'The Sanctuary of Meter Phileis near Philadelphia', EA 6 (1985) 111-25. Most of my examples are taken from CMRDM.

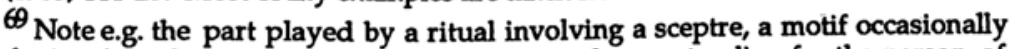
depicted on the accompanying sculptures, and even standing for the person of

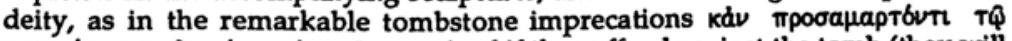

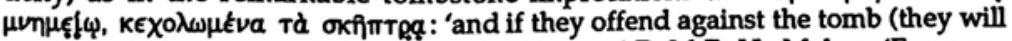
encounter) the anger of the sceptres' (Saittae, AD 26-7; H. Malay, 'Funerary Inscriptions from Northeast Lydia', ZPE 47 [1982] 113, no. 1). 
of the same words or their immediate cognates in the New Testament. And beside these we have other words, like Ikavomot $\epsilon \omega$ and $\delta a \phi \epsilon \zeta \gamma \omega$ in senses requiring their inclusion in a theological dictionary of rural Lydian religion. To these I may add the following New Testament words, all in religious senses, which feature in other texts of the same cults and locality:

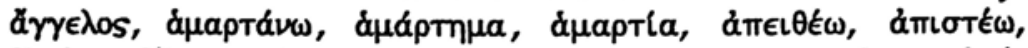

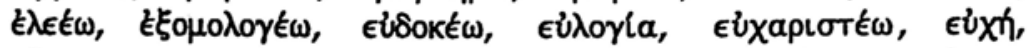

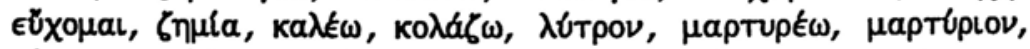

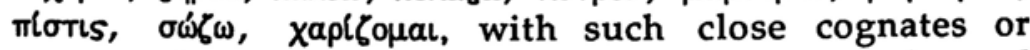

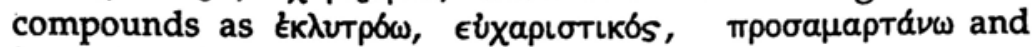
immperla. Apart from all these we have religious concepts expressed by words other than those present or even congenial

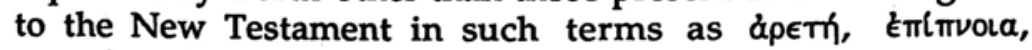
$\nu \epsilon \mu \epsilon \sigma \epsilon \omega, \nu \epsilon \mu \epsilon \sigma s$, ptoual.

Enough has been said to indicate the usefulness of further study of this terminology. Perhaps the question recurs whether there could conceivably be Christian influence, at least on the vocabulary, as the more explicit case-histories are almost all of the second or third centuries. But this cult-complex is essentially rural, indigenous, and culturally removed from Hellenized city life, while its naive theology of offence, revenge, confession, satisfaction and submissive fear is integrated with indigenous ideas capable of much wider illustration in Anatolia. There is no hint, for instance, of any aspiration to a view of 'salvation' as a counter to the Christian salvation. Thought the word $\sigma \omega \sigma^{\prime} \omega$ occurs in our list, it is relatively rare in this district, and the concept of 'salvation' is not prominent, as it is further east.

We are not in fact attempting to argue that this language stands at all close to the New Testament, but that it cannot be excluded from the evidence for the linguistic totality of which it and the New Testament idiolect alike form a part. But whereas we are accustomed to envisage the specifically theological words as standing in relative isolation, so that we may give free rein to interpreting them as peculiarly Jewish and Christian and as representing a Jewish or very primitive Christian creativity, the suggestion here is rather that their use is embedded in a much larger matrix, in which the nature of the relationship is a study in itself. Questions are raised about the character of Christian communication, how far it did (or may today) take over the 
language of a pagan or secular culture in a neutral, disinfected or altered sense.

\section{CONCLUDING REMARKS}

The function of this paper has been in large part to illustrate the varieties of Greek and the types of evidence which are available for consideration. Insofar as it has argued a thesis, that thesis is that New Testament Greek, or indeed any other segment of Greek, ought to be described within a total context which is less easily demarcated than the artificial textbook conception of language might suggest. Many of the words and usages we have discussed are barely represented in the lexica, and some few actually unrecorded in them.

We have worked mainly with the inscriptions, and it may be asked whether in any case the language of epigraphy, intended for a lasting record on stone, was not likely to differ widely from the popular style of an ephemeral papyrus letter or school exercise. There is indeed plenty of flowery formality, officialese and bombast, but the styles of epigraphy are extraordinarily diverse. Some of the cases we have cited are expressed in very crude or eccentric Greek indeed. Here is not one more variety of Greek, but a different cross-section through another spectrum, whose lower end is as bizarrely sub-literate as anything the papyri can show. There is on any view a body of Greek linguistic material in the inscriptions, comprising tens of thousands of texts, which we cannot afford to neglect, especially as their richest harvest is in Asia Minor under Imperial Rome, and this touches closely the environment of the New Testament. ${ }^{70}$

70 For discussion of the linguistic character of very diverse styles of inscription c. e.g. K. J. Dover, 'The Language of Classical Attic Documentary Inscriptions', Transactions of the Philological Society (1981) 1-14; H. J. Leon, The Language of the Greek Inscriptions from the Jewish Catacombs of Rome', TAPA 58 (1927) 210-33. In the matter of varieties of Greek style I am further indebted to Dr C. C. Caragounis, who suggests to me that the diglossy so apparent in MGk in the gulf

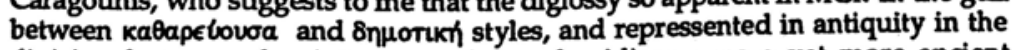
division between the Atticists and popular idiom, was a yet more ancient phenomenon, where the literary Attic was itself considerably removed from ordinary speech, which for that period is scarcely accessible to us. The corollary that popular Greek has a yet stronger continuity and antiquity than appears from the influence of the Greek Bible and the linguistic conservatism of literature strengthens the case for the careful diachronic study of the language, embracing 
I hope these reflections may serve as providing some background to the pinpointing of a lexical need. We have come to rely very much on Moulton and Milligan for collected information about non-literary Greek usage. Their compilation is still a classic of its kind, but is now inadequate for modern needs. It was in conception suggestive and illustrative rather than systematic. It was made from the compiler's own breadth of reading, unassisted by the comprehensive indexing in Preisigke's Wörterbuch, which appeared only when $M M$ was nearly complete, far less by the new facilities of the computer search. And the non-literary documents used by $M M$ were essentially the papyri. Neither they nor their successors have used the inscriptions more than sparingly. Yet the quantity of material in both categories is now several times larger than was known in their day. And the great need now is for the more sophisticated analysis and description of this material in terms of improvements in lexicographical theory, and with careful discrimination of period, style and usage. $M M$ was never more than a valuable repository of linguistic illustration, a startingpoint for critical interaction, never a definitive authority. ${ }^{71}$

The conference in December 1985 at Princeton resulted from the proposal initiated in 1980 at Macquarrie University, Sydney, under the leadership of Professor E. A. Judge, to replace

\footnotetext{
MGk also. It is certainly striking that many 'modern' lexical and syntactical features can be traced to origins at least as early as the New Testament, and that these are well represented in the inscriptions. Such are the increasing prevalence of diminutives in tov, syncopated numerals like $\pi \epsilon \nu T \hat{\nu} \nu T a$ (CJ 596, Venosa, n.d.), words like $\psi \omega \mu l o v$, budplov, etc. Cf. also K. Mickey, 'Dialect Consciousness and Literary Language: An Example from Ancient Greek', Trans. Phil. Soc. (1981) 3566; F. Pfister, Vulgärlatein und Vulgärgriechisch', Rheinisches Museum 67 (1912) 195-208. For the significance of epigraphy as a practice see also Ramsay McMullen, The Epigraphic Habit in the Roman Empire', AJP 103 (1982) 233-46; J. C. Mann, 'Epigraphic Consciousness', IRS 75 (1985) $204-6$.

71 For a fuller discussion of $M M$ see my article in NooT 24 (1982) 97-123. The first volumes of F. Preisigke, Worterbuch der griechischen Papyrusurkunden (Berlin, privately published) began to appear in 1925 . The fascicles of $M M$ were produced in the period extending from 1914 to 1929 . For further debate over the character of NT Greek see also G. C. Neal, 'In the Original Greek', Tyndale House Bulletin 12 (1963) 12-16; N. Turner, 'The Unique Character of Biblical Greek', VT 5 (1955) 208-13; Modern Issues in Biblical Studies. Philology in New Testament Studies', ExpT 71 (1959-60) 104-7; 'The Literary Character of New Testament Greek', NTS 20 (1973-4) 107-14; 'Jewish and Christian Influence on New Testament Vocabulary', NooT 16 (1974) 149-60; M. Silva, review, N. Turner, Christian Words , TJ n.s. 3 (1982) 103-9; G. Mussies, 'Greek as the Vehicle of Early Christianity', NIS 29 (1983) 356-69; J. W. Voelz, 'The Language of the New Testament, ANRW 2.25 .2 (1984) 893-977.
} 
$M M .{ }^{72}$ The work commenced in 1980 has already led to the production of the first three volumes of the series New Documents Illustrating Early Christianity edited by G. H. R. Horsley. ${ }^{73}$ This series performs the double function of offering the New Testament scholar a carefully selected digest of relevant recent publications of documents, with discussion and commentary, and of assembling materials with a view to the proposed new $M M$. The Princeton conference brought together an international group of interested persons, including theologians, linguists, classicists and directors of computerized projects. While the conference had no executive function, it provided an ideal forum for the exchange of information, ${ }^{74}$ and hence for establishing the basis for an international collaboration directed from Australia, with the aim of producing the finished dictionary in ten years. It is envisaged as strictly a lexicon of the New Testament in the light of the non-literary sources. This restriction in scope is a practical necessity, designed to complement existing dictionaries in catering for a readership concerned with its designated field. This is not to discount the wider continuum of the whole literary and linguistic context, nor to isolate the arbitrary segment of vocabulary contained in the New Testament from the vast lexical stock included in the whole environmental langue. The aim will be to present the segment which meets the special need, with special reference to the evidence of the documents, but without thereby neglecting the attempt to give a balanced, analytical description of the usage of each word. This does not meet the breadth of the need even

\section{See the report in NooT 24 (1982) 97-123.}

73 G. H. R. Horsley, New Documents Illustrating Early Christianity (North Ryde NSW; The Ancient History Documentary Research Centre, Macquarie University 1981-3), the three volumes so dated reviewing the documentary publications of the corresponding years 1976-8, five years earlier. The volumes have actually appeared later than the year of official publication, and a fourth volume is now in preparation.

74 It may be helpful to note the scope of some of the projects represented: the Princeton epigraphic project on the cities of Ionia, directed by D. F. McCabe; the Cornell project on the inscriptions of Attica, directed by K. Clinton; the Thesaurus Linguae Graecae at the University of California at Irvine, directed by T. F. Brunner; the computerization of the major collections of papyri at Duke University, North Carolina, directed by J. F. Oates; the Septuagint lexicon project at the University of Pennsylvania, directed by R. A. Kraft and E. Tov; the storing of the results of several of these projects on the Micro-Ibycus laser disc developed by D. W. Packard at Princeton. 
within biblical Greek, for a lexicon of the Septuagint is likewise a pressing requirement. To include this, however, is beyond the manageable scope of the present project, and involves very special problems of text, of internal diversity and of translation Greek, where we may now look forward to the work under E. Tov and R. A. Kraft as a companion piece rather than a constituent part of the present initiative.

I conclude with three observations as we look to this future perspective. (1) 'Of the making of dictionaries there is no end.'75 There are still extremely complex tasks to be undertaken with materials which are very rich and yet fragmentary. It may even be that our present study makes its retrospective contribution to Homeric lexicography. (2) We are still left with the problem of 'Christian words', and I am tempted to express an irreverent interest in 'un-Christian words'. It may be part of the description of New Testament language to ask the converse question whether certain words are actually avoided for their possible pagan or other unhelpful connotations. The argument from silence is ever-dangerous - but iyleta was a goddess and the word is absent from the New Testament; and Paul (unlike Jesus) never uses the 'friendship' words as a model of relationships of God and man. Were they too misleadingly evocative of the formalized dependency of Roman amici? (3) The problems of inter-cultural communication, which lie outside the essentially linguistic focus of this paper, are a very important area of application of the kind of study it represents. How did Paul, or others among the first Christians, approach those whose minds were pervaded with pagan cult?76 What did 'Christian words' mean to their audience, and were 'meaningful' words sometimes a dangerously misleading vehicle? Are there lessons for us today in the fruits of a deeper analysis of the complex relationships of primitive Christianity to its linguistic and social environment?

75 Cf. O. A. Piper, New Testament Lexicography: An Unfinished Task', in Festschrift to Honor F. Wilbur Gingrich, ed. E. H. Barth and R. E. Cocroft (Leiden, Brill 1972) 177-204, esp. 177, 202.

76 I am thinking here first of the Gentile mission, for which Acts 14:8-16 (Lystra) and Acts 17:16-34 are the classic passages. The two cases are very different, and the former is an unparalleled account of a confrontation with indigenous Anatolian cult, where the problem of non-communication looms large. The question must be asked how far primitive Christianity ever penetrated the rural areas of Anatolia away from the Hellenized cities and how far barriers of communication, whether directly. linguistic, as at $\mathrm{Cy}$ ystra, or cultural and religious, were onerative in the situation 